\title{
Critical Success Factors for Implementing Building Information Modeling (BIM) in Construction Industry
}

\author{
Mohammed A Enshassi ${ }^{1}$ Khalid A Al Hallaq $^{2}$ and Bassam A Tayeh ${ }^{2 *}$ \\ ${ }^{1}$ Research Assistant, Department of Civil Engineering, Islamic University of Gaza, Palestine \\ ${ }^{2}$ Assistant Professor Department of Civil Engineering, Islamic University of Gaza, Palestine
}

Submission: May 23, 2019; Published: June 18, 2019

*Corresponding author: Bassam A Tayeh, Assistant Professor of Civil Engineering Department, Islamic University of Gaza, Gaza, Palestine

\begin{abstract}
Purpose: Building Information Modeling (BIM) is the best tool to improve construction processes. However, BIM did not implement successfully. So, solving these issue needs a better knowledge about Critical Success Factors (CSFs)
\end{abstract}

Aim: The aim of this paper is to investigate Critical Success Factors (CSFs) to BIM implementation in construction industry.

Design/methodology/approach: To investigate the research objectives, a quantitative approach was adopted, and a structured questionnaire was designed. A total of sixty-eight copies of questionnaire were distributed and sixty-five of them were satisfactory completed, making the total response rate $=95.58 \%$. Snow-ball sampling method helped to obtain a high rate of response and thus increase accuracy.

Findings: The most important Critical Success Factors (CSFs) to implementing BIM were 4D construction sequencing and simulation, clash detection, support from top manager, earlier and accurate 3D visualization of design, and improved construction project performance and quality.

Originality/value: As a results of this research a CSFs of BIM implementation were investigated. This will help the construction companies to implement BIM successfully. This research considers a baseline for future scholars who aim to find solutions to implement BIM successfully in construction projects in Gaza Strip.

Keywords: Building Information Modeling (BIM); Critical Success Factors (CSFs); Construction industry; Framework; Gaza Strip

\section{Introduction}

Similar to other industries, the construction firms took advantageous from information and communication technology (ICT) application [1]. With respect to productivity and effectiveness, Building Information Modeling (BIM) offers advantages for implementation, design, scheduling, and facility management [2].

Succar [3] defined BIM as "a set of interacting policies, processes and technologies generating a methodology to manage the essential building design and project data in digital format throughout the building's life-cycle". BIM has developed civil engineering industries and construction process over the last years [4]. The implementation of BIM has been slowed particularly in small firms [5,6]. Many solutions have either concentrated onto technical issues (for example, software interoperability and software and training costs) or non-technical issues (for example, cultural change and legal uncertainties) [4,7]. However, solving these issues needs a better knowledge about Critical Success Factors (CSFs) to implement BIM successfully [8].
Rockart [9] defined CSFs as: "few key areas of activity where favorable results are absolutely necessary for a manager to reach his/ her goals." Therefore, CSFs for BIM implementation was defined by Won [10] as a group of key areas that motivate stakeholders to alter their traditional project delivery system to implement BIM collaboratively from the beginning of design phase to facility management phase.

BIM usage is various at all stages of the construction project lifecycle: owner used it to comprehend project requirements. Design team used BIM to design, analyze, and develop project. Contractor used it to manage the project and facility manager used it during operation phases [11]. Management teams may use BIM to collaborate, visualize and manage construction work better $[4,12,13]$.

BIM technology offers a range of direct and indirect benefits and has made the whole design and construction procedure more simplified and obvious in many sides [14]. It is not unnoticed by 


\section{Civil Engineering Research Journal}

experts in construction industry that the BIM implementation may reduce re-work, waste, delay and reduce overall cost to name a few [15]. Azhar [4] reported that BIM can reduce unbudgeted change by $40 \%$, and reduce the project time of completion by $7 \%$, and the time to make a cost estimate by $80 \%$. Eastman [6] in another project stated that BIM as a result of earlier clash detection saved $3-5 \%$ of whole project cost and $2-4 \%$ of overall time. As the primary principle of integrated project delivery (IPD) to integrate systems, parties, and business structures and improve collaborative process, BIM also used to integrate design and construction and encourages more collaboration and communication between all stakeholders to improve efficiency, reduce costs and waste through all phases of the project life cycle [6,13,16-19].

\section{Literature Review}

BIM is able to do effective and fast decision-making, this done through instantaneous processes [20]. Azhar [4] suggested that building information model helps to choose the best position of the construction on the site. BIM also can reduce risk distributed with the same contract like claims or litigation [8,21-23]. Eastman [6] reported that building information model formed at the design stage must be linked with construction plan and other scheduling tools. These coordination and planning activities assist project team to manage construction implementation more effectively and efficiently and forecast possible error and opportunities for substantial improvement $[6,20]$. BIM could give more predictable environmental data (for example, predict airflow and weather) and it may contribute to establish a model of good practice for BIM and sustainability implementation [24,25].

Comprehensiveness of predictable data improve the lifecycle data management $[26,27]$. On the other hand, sustainable solution may lead to reducing carbon emissions and improve sustainable building design, construction and operation $[4,6,13,22,28]$. By using BIM, building proposals can be effectively analyzed, quickly simulated, and assisting better-quality and innovative solutions, this help to improve construction project performance quality and increase productivity $[3,4,20,22,23,29-33]$. The digital BIM model gives data for energy analyses and estimations of the consumption of energy may be determined [14,22,34]. The model can be determined lower energy consumption as well as determine where corrections are needed [21,24]. Azhar [21] and Eastman [6] asserted that an assessment of energy analyses throughout the design stage consider as a CSF for a BIM successful implementation.

Also, most of proposals are better understood by the non-technical people such as clients through accurate visualization and prefabrication of materials because they able to see end product off-site; so, client's request for BIM maybe increase $[4,8]$. The traditional method of documentation was used paper [35]. When BIM came up, it transferred the paper-based methods and placed them on a computer-generated environment, as a result of that BIM supply a high level of efficiency, management, and integrating of project documentation of the site $[3,6,22,35]$. Matarneh \&
Hamed [30] and Bryde [18] concluded that the ability of BIM to reducing the time needed for documentation process in construction projects and produce flexible documentation output. With BIM-based practices, organizations may get a greater Return on Investment (ROI) by means of a better design process which rise the value of project data in each phase and reduce the requirement to produce this data $[8,36]$. Selecting BIM services that meet investment goals of an organization are important for increasing ROI through BIM adoption [10].

Visualization of design allows building components to be built and viewed in a simulated environment and combine all these components inside BIM model (i.e. combining structural, architectural, mechanical, plumbing and electrical models) [22]. Also, Sun [37], Azhar [4] and Manning \& Messner [36] stated that 3D visualization can be easily and quickly generated in a building and it helps project professionals to do more accurate development. 4D modelling allows stakeholders to visualize construction sequencing, fabrication and planning of suggested construction methods as well as, identify and reduce problems related to off-site construction by providing offsite prefabrication models [4,6,8,28,3739]. So, visualization is one of the CSFs of BIM implementation [34,40-42].

In construction document phase most companies used BIM to make a design code checking to check construction projects $[4,6,22,43]$. BIM also is used for 3D or 4D clash discoveries [44]. BIM make physical and functional features of a construction and give a chance to correct design errors and implement any changes before a building is actually established and this is consider as a CSF for implementing BIM [4,18,30,37].

Antwi Afari [22] and Bansal [45] conduct that physical and geographical characteristic of any facility is reliant on three main things: early construction site works, layout of temporary site facilities, and construction site safety planning. Senior manager in the organization is responsible for safety in general and the ability of safety trainers to improve the quality of training meetings [46]. The results of senior manager responsibilities to site safety training are little injury occurrences and assist to develop a company's safety culture [47]. Zhang [48] stated that BIM is used to recommend a rule-checking safety system which particularly use for fall protection like guardrails. Thus, BIM simplifies scheduling, 3D modelling, and joining them together to visualize safe construction activities.

BIM make production of shop drawings of the building and assembly of structural systems more quickly and easily than traditional methods $[4,6-8,37]$. BIM also is used by facility management department effectively by using the all information in the model for maintenance operations and managing the building over project time $[4,8,20,37]$. Anticipating benefits from the use of BIM is reduced transaction costs . BIM potentially used to transaction and overall cost via modification of specifications, drawings, and bills of quantities [36]. In this context many Software companies build BIM software in cost estimation characteristics, 


\section{Civil Engineering Research Journal}

material quantities are also automatically extracted and can updated when designer do any change in the model [4,37]. Some of extra costs due to CAD rework, computer upgrades or training can be minimized by implementing BIM from the initiation stage of projects [18].

The construction process has huge amount of data and information such as enormous specification, drawings and bills of quantities and this information is hard to manage [22]. The practitioners often manage Information and exchange knowledge manually, so, this process consumes valuable time and probably expands cost through loss of data through information exchange process [50]. Won [10] and Azhar [4] suggested that BIM ability to share information easily and quickly among project participants was measured as a most CSF to BIM implementation. Buildings which complex in shapes and systems commonly have many conflicts and clashes between trades, this complex building projects need inter-organizational associations [10,51]. Trust between various project practitioner is crucial to assure success in inter-organizational ventures $[51,52]$. Due to the nature of work in these inter-organizational projects there is a substantial need for well integration, coordination, and cooperation of project members [53].

Table 1: Summary of BIM CSFs.

\begin{tabular}{|c|c|c|}
\hline Code & BIM CSFs & Reference \\
\hline CSF 1 & Support from top manager & {$[8,22,63]$} \\
\hline CSF 2 & Effective decision making & {$[8,4,20]$} \\
\hline CSF 3 & Reduced claims or litigation (risks) & {$[8,21-33]$} \\
\hline CSF 4 & Improve the lifecycle data management & {$[26,27]$} \\
\hline CSF 5 & Effective coordination and planning of construction works & {$[6,8,20]$} \\
\hline CSF 6 & Predicting environmental analysis and simulation & {$[4,6,22,28]$} \\
\hline CSF 7 & Establishment a model of good practice for BIM and sustainability implementation & {$[20,25-27]$} \\
\hline CSF 8 & Improved construction project performance and quality & {$[3,4,8,10,20,22,23,29,20,30-33,44,61,62]$} \\
\hline CSF 9 & Improve productivity & {$[3,4,8,10,20,22,23,29,30-33,44,61,62$} \\
\hline CSF 10 & Reduce energy consumption & {$[6,14,21,22,24,34]$} \\
\hline CSF 11 & Client's request for BIM & {$[4,8]$} \\
\hline CSF 12 & Providing BIM models for offsite prefabrication & {$[4,6,28]$} \\
\hline CSF 13 & Improve documentation process & {$[3,6,8,18,22,30,35]$} \\
\hline CSF 14 & Greater Return On Investment (ROI) & {$[8,10,36]$} \\
\hline CSF 15 & Earlier and accurate 3D visualization of design & {$[4,22,34,37,36,22,40,41,42,44]$} \\
\hline CSF 16 & 4D construction sequencing and simulation & {$[4,8,34,37,39]$} \\
\hline CSF 17 & Easier code checking & {$[8,4,37,43]$} \\
\hline CSF 18 & Clash detection & {$[4,6,8,18,22,30,37,44]$} \\
\hline CSF 19 & Improved site layout planning and site safety & {$[8,22,45-48]$} \\
\hline CSF 20 & Providing BIM models for shop drawings & {$[4,6-8,37]$} \\
\hline CSF 21 & Quickly and easily assembly of structural systems & {$[4,6-8,37]$} \\
\hline CSF 22 & Effective facility management & {$[8,4,20,37]$} \\
\hline CSF 23 & Effective cost estimation & {$[8,4,37]$} \\
\hline CSF 24 & Reducing construction project cost & {$[8,18,22,30,36,49]$} \\
\hline CSF 25 & More training programs for cross-field specialists in BIM & {$[8,22,25,63]$,} \\
\hline CSF 26 & Managing people resistance to BIM change & [8] \\
\hline CSF 27 & Enhancing exchange of information and knowledge management & {$[4,8,10,22,50]$} \\
\hline CSF 28 & Increase trust between various project practitioner & {$[8,22,51,52]$} \\
\hline CSF 29 & $\begin{array}{l}\text { Provide collaboration techniques and a commitment protocol between various project } \\
\text { members. }\end{array}$ & {$[8,11,18,22,25,54-59]$} \\
\hline CSF 30 & Facilitates the sharing of information during a building's lifecycle & {$[8,22,26,40]$} \\
\hline
\end{tabular}

Several scholars have explained how BIM can improve cooperation during all project stages (initiation, design, construction, and maintenance of a development) [54,55]. Collaboration among project practitioner is a primary requirement for achieving the preferred points of project cost and quality in the construction in- dustry, therefore, there is a significant need to evolve collaboration techniques and a commitment protocol between various project members [11,56-58]. Bryde [18] and Barlish \& Sullivan [59] argued that the use of BIM as a collaborative tool has a major impact to project performance. For instance, Won [10] and Erik Eriksson, 


\section{Civil Engineering Research Journal}

Nilsson [60] support the importance of collaboration between stakeholders to allow information sharing and knowledge transfer. Popov, Juocevicius [26] stated that BIM implementation promote sharing of information during a building's life-cycle, while Kymmell [40] asserted that early collaboration between project stockholders substantially influences BIM implementation. To conclude Lee et al. [61] and Hegazy et al. [62] supported that BIM support efficient collaboration among project participant to share information between them. Also offers an integrated solution for numerous ICT systems. Table 1 illustrates a summary of BIM CSFs [63].

\section{Methodology}

This study engaged quantitative data to perform research aim, structured questionnaire was designed for data collection and analysis. The questionnaire was distributed to 68 engineers who have some experience about BIM applications in construction industry in Gaza Strip in Palestine.

\section{Questionnaire design}

The questionnaire is divided into two sections. In questionnaire cover page the researcher explain why this questionnaire was developed and identified research aim and objectives as well as mentioned the main sections of the questionnaire. The first section is about respondents' personal information and divided into five question about respondent's gender, education level, nature of work, position and work experience respectively. Second section of the questionnaire contain thirty questions about factors that lead to success in respondent's company in BIM implementation.

\section{Questionnaire verification}

Face validity: The validity of the questionnaire designed was tested by present the first draft of the questionnaire to 6 experts Results

Table 2: RIl's and test values for Critical success factors.

\begin{tabular}{|c|c|c|c|c|c|c|c|}
\hline \# & Critical Success Factors (CSF) & Mean & Std. Dev & RII (\%) & T value & $P$ value Sig. & Rank \\
\hline CSF 16 & 4D construction sequencing and simulation & 4.49 & 0.77 & 89.8 & 15.41 & 0 & 1 \\
\hline CSF 18 & Clash detection & 4.48 & 0.83 & 89.54 & 14.33 & 0 & 2 \\
\hline CSF 1 & Support from top manager & 4.45 & 0.81 & 88.92 & 14.38 & 0 & 3 \\
\hline CSF 15 & Earlier and accurate 3D visualization of design & 4.31 & 0.98 & 86.15 & 10.73 & 0 & 4 \\
\hline CSF 8 & Improved construction project performance and quality & 4.25 & 0.79 & 84.92 & 12.7 & 0 & 5 \\
\hline CSF 23 & Effective cost estimation & 4.2 & 0.87 & 84 & 11.13 & 0 & 6 \\
\hline CSF 25 & More training programs for cross-field specialists in BIM & 4.18 & 0.73 & 83.69 & 13.15 & 0 & 7 \\
\hline CSF 26 & Managing people resistance to BIM change & 4.17 & 0.82 & 83.38 & 11.48 & 0 & 8 \\
\hline CSF 21 & Quickly and easily assembly of structural systems & 4.14 & 0.97 & 82.77 & 9.5 & 0 & 9 \\
\hline CSF 13 & Improve documentation process & 4.14 & 1.01 & 82.77 & 9.06 & 0 & 10 \\
\hline CSF 7 & $\begin{array}{l}\text { Establishing a model of good practice for BIM and sus- } \\
\text { tainability implementation }\end{array}$ & 4.11 & 0.83 & 82.15 & 10.74 & 0 & 11 \\
\hline CSF 5 & $\begin{array}{l}\text { Effective coordination and planning of construction } \\
\text { works }\end{array}$ & 4.09 & 0.96 & 81.85 & 9.14 & 0 & 12 \\
\hline CSF 20 & Providing BIM models for shop drawings & 4.09 & 1 & 81.85 & 8.85 & 0 & 13 \\
\hline CSF 4 & Improve the lifecycle data management & 4.06 & 0.95 & 81.23 & 9.01 & 0 & 14 \\
\hline
\end{tabular}

with academic knowledge in BIM hardcopy by hand or softcopy by email. These experts made a very helpful and important modification to questionnaire such as: clarify some technical expressions, add some questions and Audit Arabic and English language. These modifications help to developed final version of the questionnaire.

Pilot study: The size of the pilot sample depends on the actual sample size. According to Thomas [64] a sample of round 30-50 people should be enough to identify any substantial bugs in the system. As a result of that, 30 copies of the questionnaire were distributed conveniently to respondents from the target group. All copies were collected, coded, and analyzed by using Statistical Package for the Social Science IBM (SPSS) version 22.

\section{Population and sample}

The questionnaire was formed and distributed in March 2019. Target population of the questionnaire includes civil engineers, architects, electrical engineers, mechanical engineers who have some experience about BIM applications in construction industry in Gaza Strip in Palestine. Snow-ball sampling method was conducted as a sampling method in the research. In this sampling method the initial respondents are chosen by non-probability methods and then other respondents are suggested by the initial respondents [65]. Because the number of people who are familiar with BIM implementation is limited and there are limited sources for finding engineers who have experience in this specific topic, snow-ball sampling method can be the best technique to create a network of professional contacts [66]. In questionnaire distribution stage face-to-face and web-based survey was used. A total of sixty-eight copies of questionnaire were distributed and sixty-five of them were satisfactory completed, making the total response rate $(65 / 68) *(100)=95.58 \%$. Snow-ball sampling method helped to obtain a high rate of response and thus increase accuracy. 


\section{Civil Engineering Research Journal}

\begin{tabular}{|c|c|c|c|c|c|c|c|}
\hline CSF 11 & Client's request for BIM & 4.05 & 0.96 & 80.92 & 8.8 & 0 & 15 \\
\hline CSF 17 & Easier code checking & 4.03 & 0.9 & 80.62 & 9.23 & 0 & 16 \\
\hline CSF 27 & $\begin{array}{l}\text { Enhancing exchange of information and knowledge } \\
\text { management }\end{array}$ & 3.98 & 0.89 & 79.69 & 8.89 & 0 & 17 \\
\hline CSF 14 & Greater Return on Investment (ROI) & 3.98 & 0.96 & 79.69 & 8.27 & 0 & 18 \\
\hline $\operatorname{CSF} 9$ & Improve productivity & 3.97 & 0.97 & 79.38 & 8.08 & 0 & 19 \\
\hline CSF 3 & Reduced claims or litigation (risks) & 3.95 & 0.84 & 79.08 & 9.19 & 0 & 20 \\
\hline CSF 22 & Effective facility management & 3.94 & 0.9 & 78.77 & 8.41 & 0 & 21 \\
\hline CSF 30 & $\begin{array}{l}\text { Facilitate the sharing of information during a project } \\
\text { lifecycle }\end{array}$ & 3.92 & 1.02 & 78.46 & 7.3 & 0 & 22 \\
\hline CSF 24 & Reducing construction project cost & 3.89 & 0.95 & 77.85 & 7.54 & 0 & 23 \\
\hline CSF 29 & $\begin{array}{l}\text { Provide collaboration techniques and a commitment } \\
\text { protocol between various project members. }\end{array}$ & 3.83 & 0.89 & 76.62 & 7.49 & 0 & 24 \\
\hline CSF 10 & Reduce energy consumption & 3.82 & 1.03 & 76.31 & 6.39 & 0 & 25 \\
\hline CSF 2 & Effective decision making & 3.82 & 1.16 & 76.31 & 5.68 & 0 & 26 \\
\hline CSF 19 & Improved site layout planning and site safety & 3.8 & 1.05 & 76 & 6.15 & 0 & 27 \\
\hline CSF 28 & Increase trust between various project practitioner & 3.66 & 1 & 73.23 & 5.31 & 0 & 28 \\
\hline CSF 6 & Predicting environmental analysis and simulation & 3.49 & 1.11 & 69.85 & 3.59 & 0.001 & 29 \\
\hline CSF 12 & Providing BIM models for offsite prefabrication & 2.98 & 1.01 & 59.69 & -0.12 & 0.902 & 30 \\
\hline \multicolumn{2}{|r|}{ All statements } & 4.01 & 0.52 & 80.17 & 15.54 & 0 & \\
\hline
\end{tabular}

Table 2, shown that " $4 \mathrm{D}$ construction sequencing and simulation" was ranked in the first position with RII equals (89.80\%). This result illustrates the importance of 4D construction sequencing and simulation for the success of the organization in BIM implementation. This is related to importance of time schedule to construction project. All of projects need to deal with time effectively to save cost and eliminate delays. The study of Sun [37] and Tsai [8] supported this factor as one of the main CSFs facing organization in BIM implementation.

"Clash detection" was ranked in the second position with RII equals (89.54\%). This result shows the importance of clash detection for the success of the organization in BIM implementation. This may be due to the ability of clash detection to minimize errors by predicting the conflict and faults in design stage before start construction process on field. In addition, clash detection process will definitely reduce building time. As well as provide well understanding of construction functionalities before onsite construction. Tsai [8] findings support this result and it was ranked clash detection in second position by respondents.

"Support from top manager" was ranked in the third position with RII equals (88.92\%). This result illustrates the importance of support from top manager for the success of the organization in BIM implementation. Actually, this result is reasonable because the top manager is one of the most influence member in construction projects. For instance, if one company want to adopt new technology such as BIM, it consults the top manager of the company. So top manager opinion is crucial to decision making. The result obtained aligns with the findings of Tsai [8] which indicated that support from top manager consider the most important critical success factor facing organization in BIM implementation and it was ranked in the first positions by respondents.
"Earlier and accurate 3D visualization of design" was ranked in the fourth position with RII equals (86.15\%). This result reveals the importance of earlier and accurate 3D visualization of design for the success of the organization in BIM implementation. Due to the lake of experience of some stakeholders in the construction process, it is difficult to imagine how the final shape of building. So, 3D visualization was found to help all stakeholders to see their construction before it is actually established. The use of 3D models also may eliminate problems associated to off-site buildings. The result obtained is agree with the study conducted by Antwi-Afari [22] and Matarneh \& Hamed [30].

"Predicting environmental analysis and simulation" was ranked before the last position with RII equals (59.69\%). This means that the ability of BIM to Predicting environmental analysis and simulation is not so important to implement BIM. This is related to availability of data from other reliable sources such as Palestinian Meteorological Department. In addition, the environmental conditions in the Gaza Strip are moderate and do not significantly affect the construction process. As well as The rate of rainfall is relatively low compared to other countries. This results in line with the conclusions of Antwi-Afari [22].

"Providing BIM models for offsite prefabrication" was ranked in the last position with RII equals (59.69\%). This means that the ability of BIM to provide models for offsite prefabrication is not important to implement BIM. This results may interpret as project in Gaza Strip not very complex to build offsite prefabrication models to it. And other factor is more important in case of Gaza Strip. This result totally disagrees with Antwi-Afari [22] outcomes which ranked Predicting environmental analysis and simulation in the sixth position. 


\section{Civil Engineering Research Journal}

\section{Conclusion}

This paper identified thirty of BIM CSFs and these factors were ranked in order of importance. The study explains the importance of CSFs determination to implement BIM in construction industry as a tool to gain BIM significant benefits to the construction projects through project lifecycle. The findings indicated that 4D construction sequencing and simulation, clash detection, support from top manager, earlier and accurate 3D visualization of design, improved construction project performance and quality, effective cost estimation, more training programs for cross-field specialists in BIM, and managing people resistance to BIM change was the most important CSFs for implementing BIM in construction industry in Gaza Strip. Providing BIM models for offsite prefabrication, predicting environmental analysis and simulation, and increase trust between various project practitioner was ranked in the last positions by respondents.

\section{References}

1. Latiffi AA, Mohd S, Kasim N, Fathi MS (2013) Building information modeling (BIM) application in Malaysian construction industry. International Journal of Construction Engineering and Management 2(A): $1-6$.

2. Bui N, Merschbrock C, Munkvold BE (2016) A review of Building Information Modelling for construction in developing countries. Procedia Engineering 164: 487-494

3. Succar B (2009) Building information modelling framework: A research and delivery foundation for industry stakeholders. Automation in construction18(3): 357-375.

4. Azhar S (2011) Building information modeling (BIM): Trends, benefits, risks, and challenges for the AEC industry. Leadership and management in engineering 11(3): 241-252.

5. Dainty A, Leiringer R, Fernie S, Harty C (2017) BIM and the small construction firm: a critical perspective. Building research \& information 45(6): 696-709.

6. Eastman C (2011) BIM handbook: A guide to building information modeling for owners, managers, designers, engineers and contractors. John Wiley \& Sons, New Jersey, US.

7. Arayici Y (2011) Technology adoption in the BIM implementation for lean architectural practice. Automation in construction20(2): 189195

8. Tsai MH, Mom M, Hsieh SH (2914) Developing critical success factors for the assessment of BIM technology adoption: part I. Methodology and survey. Journal of the Chinese Institute of Engineers 37(7): 845858.

9. Rockart JF (1980) The changing role of the information systems executive: a critical success factors perspective.

10. Won J, Dossick C, Messner J (2013) Where to focus for successful adoption of building information modeling within organization. Journal of Construction Engineering and Management139(11): 04013014.

11. Grilo A, Jardim-Goncalves R (2010) Value proposition on interoperability of BIM and collaborative working environments. Automation in construction 19(5): 522-530.

12. Azhar S, Khalfan M, Maqsood T (2015) Building information modelling (BIM): now and beyond. Construction Economics and Building 12(4): 15-28.

13. Liu, S, Xie B, Tivendal L, Liu C (2015) Critical barriers to BIM imple- mentation in the AEC industry. International Journal of Marketing Studies7(6): 162.

14. Lee G, Park HK, Won J (2012) D3 City Project-Economic impact of BIM-assisted design validation. Automation in Construction22: 577586.

15. Ahmad I, Sein MK, Panthi K (2010) Challenges of integration and ICT's potentials in the globalized construction industry. In: Technology Management for Global Economic Growth (PICMET), Phuket, Thailand.

16. Glick S, Guggemos A (2009) IPD and BIM: benefits and opportunities for regulatory agencies. In Proceedings of the $45^{\text {th }}$ ASC National Conference, Gainesville, Florida.

17. Allen Consulting Group (2010) Productivity in the Buildings Network: Assessing the Impacts of Building Information Models. 2010, Built Environment Industry Innovation Council Melbourne, VIC, Australia.

18. Bryde D, Broquetas M, Volm JM (2013) The project benefits of building information modelling (BIM). International journal of project management31(7): 971-980.

19. Acharya NK, Lee YD, Im HM (2006) Design errors: tragic for the clients. Journal of Construction Research 7(01n02): 177-190.

20. Sebastian R (2010) Breaking through business and legal barriers of open collaborative processes based on building information modelling (BIM). In CIM World Building Congress.

21. Azhar S, Carlton WA, Olsen D, Ahmad I (2011) Building information modeling for sustainable design and LEED $®$ rating analysis. Automation in construction 20(2): 217-224.

22. Antwi-Afari M, Li H, Pärn EA, Edwards DJ (2018) Critical success factors for implementing building information modelling (BIM): A longitudinal review. Automation in Construction 91: 100-110.

23. Aranda-Mena G, Crawford J, Chevez A, Froese T (2009) Building information modelling demystified: does it make business sense to adopt BIM? International Journal of managing projects in business 2(3): 419434.

24. Eadie R, Browne M, Odeyinka H, Mckeown C, Mcniff S (2013) BIM implementation throughout the UK construction project lifecycle: An analysis. Automation in Construction 36: 145-151.

25. Olawumi TO, Chan DW (2019) Critical success factors for implementing building information modeling and sustainability practices in construction projects: A Delphi survey. Sustainable Development.

26. Popov V, Juocevicius V, Mikalauskas S (2010) The use of a virtual building design and construction model for developing an effective project concept in 5D environment. Automation in construction19(3): 357367.

27. Gecevska V, Chiabert P, Anisic Z, Lombardi F, Cus F (2010) Product lifecycle management through innovative and competitive business environment. Journal of Industrial Engineering and Management 3(2): 323-336.

28. Sebastian R, van Berlo L (2010) Tool for benchmarking BIM performance of design, engineering and construction firms in the Netherlands. Architectural Engineering and Design Management 6(4): 254263.

29. Bazjanac V (2005) Model based cost and energy performance estimation during schematic design.

30. Matarneh, R, Hamed S (2017) Barriers to the Adoption of Building Information Modeling in the Jordanian Building Industry. Open Journal of Civil Engineering 7(03): 325.

31. Khanzode A, Fischer M, Reed D (2008) Virtual design and construction (vdc) technologies for coordination of mechanical, electrical, and plumbing (MEP) systems on a large healthcare project. Journal of 


\section{Civil Engineering Research Journal}

Information Technology in Construction, (ITcon), Special issue: case studies of BIM use13: 324-342.

32. Suermann PC, Issa RR (2009) Evaluating industry perceptions of building information modelling (BIM) impact on construction. Journal of Information Technology in Construction (ITcon) 14(37): 574-594.

33. Ogunmakinde OE, Umeh S (2018) Adoption of BIM in the Nigerian Architecture and Construction (AEC) Industry. In The AUBEA Conference. Curtin Singapore, Singapore.

34. Taylor JE, Bernstein PG (2009) Paradigm trajectories of building information modeling practice in project networks. Journal of Management in Engineering 25(2): 69-76.

35. Lee C (2008) BIM: Changing the AEC Industry. PMI Global Congress 2008. Project Management Institute, Denver, Colorado, USA.

36. Manning R, Messner JI (2008) Case studies in BIM implementation for programming of healthcare facilities. Electronic Journal of Information Technology in Construction13: 446-457.

37. Sun C, Jiang S, Man Q Skibniewski MJ (2017) A literature review of the factors limiting the application of BIM in the construction industry. Technological and Economic Development of Economy 23(5): 764779

38. Huang T, Konga CW, Guo HL, Andrew B, Heng L (2007) A virtual prototyping system for simulating construction processes. Automation in construction16(5): 576-585.

39. Koo B, Fischer M (2000) Feasibility study of 4D CAD in commercial construction. Journal of construction engineering and management 126(4): 251-260.

40. Kymmell W (2007) Building Information Modeling: Planning and Managing Construction Projects with 4D CAD and Simulations (McGraw-Hill Construction Series): Planning and Managing Construction Projects with 4D CAD and Simulations. 2007: McGraw Hill Professional, US, pp. 416.

41. Fox S, Hietanen J (2007) Interorganizational use of building information models: potential for automation, informational and transformational effects. Construction Management and Economics 25(3): 289296.

42. Olatunji OA, Sher WD (2010) The applications of building information modelling in facilities management. In Handbook of research on building information modeling and construction informatics: Concepts and technologies IGI Global 1: 239-253.

43. Hartmann, T, Meerveld HV, Adriaanse A, Vossebeld N (2012) Aligning building information model tools and construction management methods. Automation in construction 22: 605-613.

44. Associated General Contractors of America (2006) The Contractors' Guide to BIM-( $1^{\text {st }}$ edn), Associated General Contractors, USA, p. 1-48.

45. Bansal V (2011) Application of geographic information systems in construction safety planning. International Journal of Project Management 29(1): 66-77.

46. Jaselskis EJ, Anderson SD, Russell JS (1996) Strategies for achieving excellence in construction safety performance. Journal of construction engineering and management122(1): 61-70.

47. O’Toole M (2002) The relationship between employees' perceptions of safety and organizational culture. Journal of safety research 33(2): 231-243.

48. Zhang S, Teizer J, Lee JK, Eastman CM, Venugopal M (2013) Building information modeling (BIM) and safety: Automatic safety checking of construction models and schedules. Automation in Construction 29: 183-195.
49. Scott D, Cheong M, Li H (2012) Web-based Construction Information Management System. Construction Economics and Building3(1): 4352.

50. Anumba CJ, Raja R, Jiayi P, Ivan M (2008) Ontology-based information and knowledge management in construction. Construction Innovation 8(3): 218-239.

51. Maurer I (2010) How to build trust in inter-organizational projects: The impact of project staffing and project rewards on the formation of trust, knowledge acquisition and product innovation. International journal of project management 28(7): 629-637.

52. Kadefors A (2004) Trust in project relationships-inside the black box. International Journal of project management 22(3): 175-182.

53. Maunula A, Smeds R, Hirvensalo A (2008) The implementation of building information modeling (BIM): A process perspective, PMS 2008 Innovations in Networks, France, p.1-8.

54. Gu N, London K (2010) Understanding and facilitating BIM adoption in the AEC industry. Automation in construction19(8): 988-999.

55. Jung Y, Joo M (2011) Building information modelling (BIM) framework for practical implementation. Automation in construction 20(2): 126133.

56. Mäki T, Kerosuo H (2015) Site managers' daily work and the uses of building information modelling in construction site management. Construction management and economics 33(3): 163-175.

57. Wu W, Issa RR (2013) BIM education and recruiting: Survey-based comparative analysis of issues, perceptions, and collaboration opportunities. Journal of professional issues in engineering education and practice 140(2): 04013014

58. Lu Y, Li Y, Skibniewski M, We Z (2014) Information and communication technology applications in architecture, engineering, and construction organizations: A 15-year review. Journal of Management in Engineering 31(1): A4014010.

59. Barlish K, Sullivan K (2012) How to measure the benefits of BIM-A case study approach. Automation in construction 24: 149-159.

60. Erik Eriksson P, Nilsson T, Atkin B (2008) Client perceptions of barriers to partnering. Engineering, Construction and Architectural Management 15(6): 527-539.

61. Lee HK, Lee YS, Kim JI (2010) A cost-based interior design decision support system for large-scale housing projects. Journal of Information Technology in Construction 1: 1-18

62. Hegazy T, Zaneldin E, Grierson D (2001) Improving design coordination for building projects. I: Information model. Journal of Construction Engineering and Management127(4): 322-329.

63. Won J, Lee G (2010) Identifying the consideration factors for successful BIM projects. In Proceedings of the International Conference on Computing in Civil and Building Engineering, Nottingham, England.

64. Thomas SJ (2004) Using web and paper questionnaires for data-based decision making: From design to interpretation of the results. Corwin Press, US.

65. Acharya AS, Prakash A, Nigam A, Saxena P (2013) Sampling: Why and how of it. Indian Journal of Medical Specialties 4(2): 330-333.

66. Gholami E, Kiviniemi A, Kocaturk T, Steve S (2017) Exploiting BIM in energy efficient domestic retrofit: evaluation of benefits and barriers. $2^{\text {nd }}$ International Conference on Civil and Building Engineering Informatics ICCBEI, 2015-04-22 - 2015-04-24, Tokyo. 


\section{Civil Engineering Research Journal}

(C) This work is licensed under Creative
Commons Attribution 4.0 License
DOI: $10.19080 / C E R J .2019 .08 .555739$

\section{Your next submission with Juniper Publishers} will reach you the below assets

- Quality Editorial service

- Swift Peer Review

- Reprints availability

- E-prints Service

- Manuscript Podcast for convenient understanding

- Global attainment for your research

- Manuscript accessibility in different formats

( Pdf, E-pub, Full Text, Audio)

- Unceasing customer service

Track the below URL for one-step submission https://juniperpublishers.com/online-submission.php 